\title{
KHAZANAH KITAB KUNING: MEMBANGUN SEBUAH APRESIASI KRITIS
}

\author{
Zaini Dahlan \\ Penulis adalah Dosen Fakultas Ilmu Tarbiyah dan Keguruan UIN SU Medan \\ E-mail: zainidahlan@uinsu.ac.id
}

\begin{abstract}
This article aims to uncover the treasures of the yellow book in a historical perspective. The methodology used in this article is the research methodology putaka or libraryresearch.The authors conclude that there are at least three characters in the writer of the 20th century who wrote the Yellow Book. Firstly, namely Ahmad Khatib (d. 1915) Minangkabau Indonesia- -bapak Islamic reformers who also was a disciple of Sheikh Bantani Nawawi (d. 1896). Second, Kyai Mahfouz Termas (d. 1919-20). The third was Muhammad Hasyim Asy'ari (1287-1366 / 1870-1947). There are two important points to explain the position and significance of the Yellow Book in schools. The first point, the authenticity of the Yellow Book for pesantren is a reference to abortion has been unquestionable. The fact that the Yellow Book was written long ago and continues to be used from time to time indicate that the book has been verified in history. The second point, Yellow Book is very important for schools to facilitate the process of deep religious understanding so as to formulate a fresh explanation but not ahistorical about the teachings of Islam, the Qur'an and Hadith. A brief description of the tradition over the Yellow Book shows how schools as an institution needs to work hard to maintain his identity while continuing to hold the development of tradition and orientation.
\end{abstract}

Keywords: Khazanah, Yellow Book, Pesantren Tradition

\section{PENDAHULUAN}

Kitab Kuning umumya dipahami sebagai kitab-kitab keagamaan Arab, menggunakan aksara Arab, yang dihasilkan para ulama dan pemikir muslim lainnya di masa lampau khususnya berasal dari Timur Tengah. Kitab Kuning mempunyai format sendiri yang khas, dan warna kertas "kekuning-kuningan". Tetapi dalam pembahasan ini, saya ingin memperluas pengertian Kitab Kuning sebagai "kitab-kitab keagamaan" berbahasa Arab, Melayu, dan Jawa atau bahasa lokal lain di Indonesia dengan menggunakan aksara Arab, yang selain ditulis ulama di Timur Tengah, juga ditulis ulama Indonesia sendiri. ${ }^{1}$

Penggunaan Kitab Kuning menjadi ciri khas yang membedakan antara pendidikan Islam ala pesantren dan pendidikan Islam non pesantren. Di pesantren

\footnotetext{
${ }^{1}$ Azyumardi Azra, Pendidikan Islam: Tradisi dan Modernisasi di Tengah Tantangan Milenium III, (Jakarta: Kencana Prenada Media, cet. 1, 2012), h. 143.
} 
selain sebagai bahan ajar, Kitab Kuning menjadi standar kelayakan dan penilaian keilmuan seorang santri terhadap bidang ilmu tertentu. Seorang santri dianggap menguasai keilmuan Islam dan layak mengajarkan ilmunya setelah mendapat penilaian dari gurunya atau kyai.

Kajian tentang Kitab Kuning dengan segala dimensinya bisa dikatakan sebagai usaha yang cukup menantang dalam memahami tradisi intelektual Islam di Indonesia. Tantangan itu, antara lain terletak dalam dua hal: pertama, berupa kesungguhan kita untuk memberikan apresiasi akademis atas karya-karya klasik, terlepas dari nilai keilmiahannya menurut kaca mata kontemporer, karena betapapun juga kitab-kitab itu merupakan warisan peradaban dan pemikiran yang sangat berharga. Kedua, merupakan kesejatian kita dalam memberi makna yang lebih segar dan kontekstual dalam memahami Kitab Kuning, yang pada gilirannya akan memberi nuansa historis dan bobot kualitatif pada pemikiran-pemikiran Islam kontemporer. Dua tantangan ini mungkin terlalu berat dan berlebihan bila ditanggung secara sendiri atau individual, tetapi tentu akan lebih ringan bila diemban bersama oleh kalangan akademis. Agaknya, akan terlalu sia-sia membangun intelektual Islam Indonesia masa depan dengan begitu saja mengabaikan kekayaan warisan intelektual masa lalu yang teramat panjang itu, yakni Kitab Kuning. ${ }^{2}$

Oleh karena itu dengan kekayaan warisan intelektual masa lalu yang amat panjang yang berada pada Kitab Kuning ini, penulis mencoba memberikan perluasan pengertian terkait dengan Kitab Kuning sehingga memungkinkan kita mengetahui secara lebih akurat tentang pembentukan dan pemapanan tradisi Kitab Kuning di Indonesia khususnya pada abad ke-20. Sebagai konsekuensi logisnya, ini akan membuka jalan bagi kita untuk melacak dan mengenali Kitab Kuning dan khazanah yang dikandungnya, penyikapan yang berkembang terhadap Kitab Kuning, dan apresiasi kritis terhadap Kitab Kuning.

\section{PEMBAHASAN}

\section{Mengenali Kitab Kuning dan Khazanah yang Dikandungnya}

Istilah "Kitab Kuning” pada mulanya diperlukan oleh kalangan luar pesantren sekitar dua darsa silam dengan nada merendahkan. Mereka memandang bahwa Kitab

\footnotetext{
${ }^{2}$ Abdurrahman Wahid, Pesantren Masa Depan Wacana Pemberdayaan dan Transformasi Pesantren, (Bandung: Pustaka Hidayah, 1999), h. 245.
} 
Kuning dianggap sebagai kitab yang ketinggalan zaman, berkadar keilmuan rendah, dan menjadi salah satu penyebab terjadinya stagnasi befikir umat. Pada mulanya, sebutan ini memang sangat menyakitkan, tetapi kemudian Kitab Kuning diterima secara meluas sebagai salah satu istilah teknis dalam studi kepesantrenan.

Berdasarkan catatan sejarah, pesantren sejak era awal telah menggunakan Kitab Kuning, di sebagian tempat disebut pula sebagai kitab klasik untuk menyebut jenis kitab yang sama dan disebut juga kitab turas. Kitab-kitab tersebut umumnya tidak diberi harakat/syakal, sehingga tidak jarang disebut juga sebagai "kitab gundul". Disebut Kitab Kuning karena pada umumnya kitab-kitab tersebut dicetak di atas kertas berwarna kuning. ${ }^{3}$

Penggunaan Kitab Kuning tersebut bahkan sebelum nama pesantren dikenal, minimal begitulah menurut Martin Van Bruinessen. Kitab-kitab tersebut biasanya terdiri dari karangan-karangan berafiliasi pada mazhab Syafi' ${ }^{4}{ }^{4}$ atau yang sering disebut Syafi'iyah serta teologi yang beraliran Ash'ariyah dan Maturidiyah serta mistisisme al-Ghazali dan yang sejenis. ${ }^{5}$

Perbedaan penyebutan buku untuk tulisan yang memakai huruf latin dan kitab untuk menyebut tulisan berhuruf Arab juga menunjukkan bagaimana dua pengaruh kebudayaan mempengaruhi dunia intelektual Nusantara. Buku-buku berhuruf latin di Indonesia sendiri baru dikenal setelah negeri ini mengalami penjajahan oleh bangsa Belanda. Sedangkan kitab-kitab berhuruf Arab bersamaan masuknya dengan penyebaran Islam di tanah air atau sudah lebih dahulu sekitar satu abad sebelum tulisan latin dikenal di Indonesia.

Sementara itu, menurut Azyumardi Azra, Kitab Kuning adalah kitab-kitab keagamaan berbahasa Arab, Melayu, Jawa atau bahasa-bahasa lokal lain di Indonesia dengan menggunakan aksara Arab, yang selain ditulis oleh ulama Timur Tengah, juga ditulis oleh ulama Indonesia sendiri. Pengertian ini merupakan perluasan dari terminologi Kitab Kuning yang selama ini, yaitu kitab-kitab keagamaan berbahasa Arab, menggunakan Kitab Kuning relevan dengan kehidupan sekarang. ${ }^{6}$

\footnotetext{
${ }^{3}$ Departemen Agama, Dirjen Kelembagaan Agama Islam, Pondok Pesantren dan Madrasah Diniyah, (Jakarta: Depag, 2003), h. 32.

${ }^{4}$ H.M. Amin Haedari, et.al., Masa Depan Pesantren, Dalam Tantangan Modernitas dan Tantangan Kmpleksitas Global, (Jakarta: IRD Press, 2005), h. 37.

${ }^{5}$ Martin Van Bruinessen, Kitab Kuning, Pesantren dan Tarekat, (Bandung: Mizan, Cet.III, 1999), h. 19.

${ }^{6}$ Azra, Pendidikan Islam, h. 143.
} 
Menurut Ali Yafie, di daerah asalnya, diseputar Timur Tengah, Kitab Kuning ini disebut al-kutub al-qadimah, sebagai sandingan dari al-kutub al-ashriyah, al-kutub al-qadimah yang beredar di kalangan pesantren di Indonesia terbatas jenisnya. Yang sangat dikenal ialah kitab-kitab fiqih, tasawuf, tafsir, hadis, tauhid dan tarikh, yang semuanya termasuk kelompok-kelompok syariah, yang banyak dikenal ialah kitabkitab nahwu dan sharaf, yang mutlak diperlukan sebagai ilmu bantu. ${ }^{7}$

Al-kutub Al-qadimah, atau yang kemudian disebut Kitab Kuning ini, telah membentuk khazanah kepustakaan dunia Islam. Oleh karenanya, kita bisa menyaksikan bagaimana perpustakaan-perpustakaan barat mengumpulkan sejumlah sangat besar Kitab Kuning ini, mulai dari kitab-kitab yang sudah tercetak sampai manuskrip-manuskrip yang sudah sangat tua, yang ada kalanya di dunia Islam sendiri sudah susah untuk mendapatkannya.

Jelas bahwa al-kutub al-qadimah merupakan suatu kekayaan kultural yang luar biasa, yang diwariskan oleh peradaban besar Islam yang mempunyai arti penting bagi manusia. ${ }^{8}$ Di sisi lain Kitab Kuning di anggap sakral, karena ditulis oleh para ulama dengan kualifikasi ganda, yakni keilmuan yang tinggi dan hati yang disinari cahaya Tuhan. Oleh karena itu, Kitab Kuning dipandang tidak memiliki cacat serta tertutup dari pemikiran kritis. ${ }^{9}$ Kitab Kuning ditulis oleh ulama salaf yang di dalamnya membahas tentang ajaran-ajaran Islam, bagi umat Islam untuk memperdalam kajian Islam, pembahasan yang relevan itu terdapat pada Kitab Kuning.

Penggunaan istilah Kitab Kuning pada kitab-kitab bertradisi klasik adalah karena kebanyakan kitab-kitab yang dimaksud dicetak di atas kertas berwarna kuning walaupun sekarang banyak juga yang dicetak menggunakan kertas putih. ${ }^{10}$ Sebelum dunia percetakan dikenal di Nusantara, kitab-Kitab Kuning diperbanyak dengan cara tulisan saduran yang dilakukan oleh para santri pada saat mengaji pada sang kyai. Teks inilah yang dijadikan pedoman oleh si santri dengan sambil menyetorkan hasil “belajar"-nya itu pada sang kyai atau biasa disebut tashih (Pembetulan), tashih ini juga berlaku pada kitab-Kitab Kuning yang tidak ditulis tapi dihafalkan lafaznya dan sampai saat sekarang ini banyak dari kalangan pesantren salaf yang menggunakan

\footnotetext{
${ }^{7}$ Ali Yafie, Menggagas Fiqih Sosial dari Soal Lingkungan Hidup, Asuransi Hingga Ukhuwah, (Bandung: Mizan, 1994), h. 52.

${ }^{8}$ Ibid., h. 53. 2008), h. 21.

${ }^{9}$ Afandi Mochtar, Kitab Kuning dan Tradisi Akademik Pesantren, (Bekasi: Pustaka Isfahan,

${ }^{10}$ Sahal Mahfud, Nuansa Fiqih Sosial, (Yogyakarta: LkiS,1994), h. 263.
} 
metode ini. Peng-ijazah-an juga seringkali dilakukan di pesantren sebagai upaya "pewarisan" hak mempelajari kitab dan ketersambungan keilmuan hingga ke tingkat penulisnya.

Kitab-Kitab Kuning tersebut ditulis dalam tulisan Arab $^{11}$ tanpa harakah atau syakal yang tentu saja membacanya membutuhkan kemampuan khusus agar bisa dibaca dan dipahami dengan baik. Kemampuan itu adalah kemampuan gramatikal bahasa Arab meliputi nahwu, sharf, dan balaghah ${ }^{12}$ atau yang biasa disebut sebagai ilmu alat (karena ia adalah alat untuk membaca dan memahami).

Kitab-Kitab Kuning kebanyakan muncul pada masa sesudah kitab al-Umm Imam al-Syafi'i dan kitab al-Muwaththa' Imam Malik, berasal dari kalangan mujtahid mazhab ataupun mujtahid muntasib yang ditulis pada abad ke 10 sampai 15 M., tapi bukan berarti bahwa sesudah masa itu tidak ada kitab yang dihasilkan seperti tampak pada karya-karya belakangan seperti karangan Syekh Nawawi al-Bantani al-Jawi pada Abad ke-19. ${ }^{13}$

Sedangkan kitab-kitab yang dikarang pada abad ke-20-an seringkali disebut sebagai kitab muta'akhirah (belakangan). Tentang kitab-kitab belakangan ini tidak dapat dikategorikan sebagai Kitab Kuning ataupun kitab klasik walau juga ada yang menyebutnya sebagai Kitab Kuning tapi bukan klasik. ${ }^{14}$ Bagi penulis sendiri lebih menyetujui untuk menyebut kitab yang dikarang pada abad ke-20 sebagai kitab muta'akhirah.

Pada umumnya desain penulisan Kitab-Kitab Kuning dimulai dengan teks dasar atau biasa disebut matan yang dikarang oleh seoranng ulama secara 'mandiri' dan tidak mengacu pada satu teks kitab lain, dan kemudian sesudahnya berupa syarh (penjelas), kemudian Syarh al-Syarh (penjelasan penjelas) atau disebut khashiyah dan juga kemudian mukhtashar (ringkasan) yang biasanya merupakan ringkasan dari

\footnotetext{
${ }^{11}$ Ini juga bisa berarti akan keberadaan kitab-kitab yang ditulis dalam bahasa Arab Pegon (Melayu Arab, Jawa Arab).

${ }^{12}$ Yang dimaksud dengan Nahwu yaitu bidang ilmu kebahasaan yang menentukan bentuk kata kerja, kata benda, subjek, predikat dan objek. Sedangkan Sharaf adalah bidang ilu kebahasan yang menelusuri metamorfosa kata dan bentuk-bentuk kata. Sedangkan Balaghah adalah bidang ilmu kebahasaan yang melacak dari bidang sastra Arab dan pengertian bahasanya (makna).

${ }^{13}$ Wafat pada 1896 M. beliau mengarang banyak syarah kitab-kitab fiqih berbahasa Arab dan banyak di antara kitab-kitab hasil karangannya yang dipergunakan di pesantren hingga sekarang.

${ }^{14}$ Sebutan untuk kitab muta'akhirah ini disebut sebagai Kitab Kuning penulis dapati dari beberapa santri di pondok pesantren di Jawa Timur yang mengaji kitab-kitab muta'akhirah dan menyebutnya sebagai Kitab Kuning.
} 
karya-karya tebal. ${ }^{15}$ Di satu sisi hal seperti ini diakui sebagai bentuk penghormatan atas kitab-kitab terdahulunya dan juga bentuk jujur dari tradisi keilmuan serta kerendahan hati untuk mengakui kitab yang dirujuknya, tapi di sisi lain hal ini dianggap sebagai bentuk kemunduran dari tradisi Islam abad pertengahan yang memang banyak menghasilkan karya-karya independen dan tidak terikat dengan satu teks.

Bagaimanapun Kitab Kuning menjadi hal yang penting bagi kalangan pesantren bahkan bagi mereka yang mencap dirinya sebagai pesantren reformis semisal pesantren-pesantren milik organisasi Muhammadiyah dan juga pada pesantren yang berafiliasi pada Islam puritan seperti milik Persis. Adapun pada pesantrenpesantren tradisional hingga saat sekarang masih tetap menggunakan Kitab-Kitab Kuning ini sebagai bahan baku utama dalam pengajaran materi agama pada para santrinya.

Pesantren yang berafiliasi dengan Persis biasanya memiliki link yang lebih kuat dengan dunia Islam Timur Tengah kontemporer sehingga kitab-kitab muta'akhirah lebih banyak dipakai daripada pesantren salaf, sedangkan pada model pesantren reformis biasanya kitab-kitab yang digunakan berkisar pada tafsir dan hadis serta lebih mneyukai kitab-kitab terjemahan dalam bahasa Indoneisa dan bukannya pada kitab fiqih klasik berbahasa Arab walau juga untuk kategori ini kitab klasik juga ditemukan di pesantren reformis sebagai koleksi para santri secara pribadi.

Dengan membaca Kitab Kuning, - kata Abdurrahman Wahid - kita sebagai umat Islam, dapat memperdalam ilmu keislaman, menjawab persoalan-persoalan yang ada pada saat ini, memberikan implikasi pada daya adaptabilitas dan responsibilitas terhadap perkembangan zaman. Kitab Kuning juga merupakan sumber asli dan dapat memberikan banyak pengetahuan tentang Islam. ${ }^{16}$

Terkait dengan khazanah yang terkandung di dalam Kitab Kuning, acapkali dipertanyakan mengapa, misalnya, hanya fiqih, ushuluddin, tasawuf, tafsir, hadis dan bahasa Arab yang menjadi disiplin ilmu pengetahuan pesantren. Tentu saja, jawaban atas pertanyaan ini hanya bisa dirumuskan secara memuaskan bila mempertimbangkan perkembangan intelektual Islam Nusantara sejak periode awal pembentukannya.

\footnotetext{
${ }^{15}$ Ungkapan yang berarti sama juga diungkapakan Martin Van Bruinessen, Kitab Kuning, Pesantren dan Tarekat, h. 141.

${ }^{16}$ Wahid, Pesantren Masa Depan, h. 236.
} 
Bagaimanapun juga, pembukuan Kitab Kuning di Pesantren sangat berkaitan dengan tradisi intelektual Islam Nusantara

kurun awal. Asal-usul dan perkembangan tradisi intelektual dan keilmuan Islam

Nusantara sejauh ini telah mengandung perhatian sejumlah sarjana dan pengamat yang menekuninya. Di antara mereka adalah Taufik Abdullah ${ }^{17}$, Kuntowijoyo ${ }^{18}$, Martin Van Bruinessen $^{19}$, Abdurrahman Wahid $^{20}$, dan Azyumardi Azra ${ }^{21}$. Dalam berbagai karyanya, masing-masing intelektual itu memberikan analisis dan penilaian atas masalah ini.

Walaupun berbeda rumusan karena perbedaan pendekatan yang digunakan, hasil kajian mereka agaknya memperlihatkan kecenderungan yang sama dalam mepertimbangkan dua faktor penting, yaitu: kontak ulama Nusantara dengan ulama Timur Tengah sebagai bagian dari proses internasionalisasi Islam, integrasi ketegangan budaya Islam dengan budaya lokal sebagai konsekuensi logis dari proses Islamisasi Nusantara. Kedua faktor ini berperan dalam membentuk dan mewarnai corak keilmuan Islam Nusantara seperti tercermin dalam tradisi pendidikan pesantren, khususnya di Jawa. $^{22}$

Dalam jangkauan yang lebih luas, Martin Van Bruinessen berpendapat bahwa Kitab Kuning yang berkembang di Indonesia pada dasarnya merupakan hasil pemikiran ulama abad pertengahan. ${ }^{23}$ Kitab Kuning ini termasuk kedalam kurikulum dalam sistem pesantren dan identik pada pesantren. Karena pesantren adalah lembaga pendidikan yang menjadikan Kitab Kuning ini menjadi pelajaran yang sangat utama dan menjadi khas suatu pesantren. Sehingga banyak dari keluaran atau alumni pesantren yang mahir dalam membaca Kitab Kuning.

Oleh sebab itulah, Kitab Kuning sangatlah penting untuk dipelajari oleh setiap lembaga pendidikan. Bukan hanya untuk alumnus yang kompeten, tetapi untuk

\footnotetext{
${ }^{17}$ Taufik Abdullah, Pemikiran Islam di Nusantara dalam Perspektif Sejarah: Sebuah Sketsa, (Prisma, cet. III, 1991), h. 16-27.

${ }^{18}$ Dengan menggunakan pendekatan sosiologi ilmu pengetahuan (sociology of knowledge), Kunto mengajukan Teori Tiga Tahap Perkembangan Keilmuan di Indonesia: Mitologi, Ideologi, dan Rasional. Lihat, (Prisma, edisi ekstra, 1994), h. 45-47.

${ }^{19}$ Martin van Bruinessen, Pesantren and Kitab Kuning: Maintenance and Continuation of A Tradition of Religious Learning, (Bandung: Mizan, 1992), h. 27-47.

${ }^{20}$ Abdurrahman Wahid, Asal-Usul Tradisi Keilmuan di Pesantren, Jurnal Pesantren, No Perdana (1984), h. 4-11.

${ }^{21}$ Azyumardi Azra, Pemikiran Sosio-Politik Islam dalam Kitab Melayu/Jawa Klasik, makalah pada Simposium Nasional I Kitab Kuning dan Lektur Islam, Bogor: ICMI, 1994.

${ }^{22}$ Mochtar, Kitab Kuning, h. 39.

${ }^{23}$ Van Bruinessen, Pesantren and Kitab Kuning, h. 37.
} 
meningkatkan pengetahuan mengenai para ulama terdahulu, hukum-hukum Islam, Akidah dan lainnya. Dalam pandangan masyarakat, Kitab Kuning merupakan formulasi final dari ajaran-ajaran Alquran dan Sunnah Nabi. Yang jelas, ia ditulis oleh para ulama dengan modal keilmuan yang tinggi dan standar moral yang bisa dipertanggung jawabkan. Ia juga ditulis dengan pena dan jari-jari

yang bercahaya. Hampir-hampir, ia dipandang sebagai karya yang tidak bercacat dan sulit untuk mengkritiknya.

Sebagai sampel, sependek penelusuran yang saya lakukan, saya akan mengemukakan tiga contoh pada abad ke-20 yang menulis Kitab Kuning. Yaitu Ahmad Khatib Minangkabau -bapak reformis Islam Indonesia- yang juga adalah murid dari Syekh Nawawi al-Bantani (w. 1896).

Ahmad Khatib (w. 1915) terkenal karena polemiknya melawan adat matrilineal di daerah asalnya dan melawan tarekat Naqsabandiyyah (yang punya pengikut paling banyak di Sumatera Barat), tapi memiliki peranan di Makkah sangat luas. Dia adalah salah seorang dari Indonesia yang pertama kali mendapatkan ijazah mengajar di Masjid al-Haram, dan dijadikan salah seorang imam di sana -sebuah keistimewaan yang biasanya diperuntukkan ulama kelahiran Makkah-. ${ }^{24}$ Kedua keistimewaan tersebut memperkuat pengaruhnya terhadap seluruh masyarakat Indonesia di Makkah. Sikap reformisnya tampak dari tulisannya -sebuah komentar terhadap kitab terdahulu mengenai usul al-fiqh, Waraqat, karya Juwayni. Akan tetapi adalah salah menganggap Ahmad Khatib hanya sebagai pemberontak tradisi; ia bahkan pun mendalaminya. Di antara muridnya ada yang reformis dan tradisionalis (beberapa di antara muridnya bahkan menjadi syaikh tarekat): dan dua kitabnya masih dipakai di beberapa pesantren. $^{25}$

Tokoh kedua adalah Kyai Mahfuz Termas (w. 1919-20), terhadap siapa kyai Jawa lebih menghormatinya ketimbang Kyai Nawawi. Dia adalah guru yang sangat dihormati dari beberapa kyai pendiri NU, yang dengan demikian, menambah reputasinya. Dia menyelesaikan pendidikannya di bawah bimbingan guru-guru Arab

\footnotetext{
${ }^{24}$ Snouck Hurgronje yang sangat membenci Ahmad Khatib menyatakan bahwa ia mendapatkan posisi-posisi ini tidak karena pengetahuannya, tapi karena mertuanya, pedagang buku dan lintah darat Salih al-Kurdi campur tangan untuk menantunya beserta Sharif 'Awn yang berhutang budi kepadanya (Adviezen Ill, 1846, 1853, 1914, 1928). Namun Snouck harus mengakui bahwa Ahmad Khatib adalah orang yang sangat terpelajar untuk ukuran Melayu.

${ }^{25}$ Ini karya us\}ul fiqh yang dikatakan, al-Nafahat 'ala Syarh al-Waraqat, dan sebuah karya pendek berbahasa Melayu mengenai doktrin, Fat\{ al-Mubin. Dia menulis lebih banyak lagi ('Abd alJabbar mencatat tak kurang dari 46 karya), namun hanya dua inilah yang masih ada di Indonesia.
} 
terbesar di Masjid al-Haram dan juga menjadi ahli qiraat al-Qur'an (dia menulis banyak kitab tentang itu). Karyanya yang paling besar adalah empat jilid kitab fiqh, yang merupakan komentar (hasyiyah) terhadap kitab yang banyak dipakai di Indonesia, ${ }^{26}$ dan dia tampaknya telah menjadi ulama Indonesia pertama yang mengajar kitab Hadis Shahih Bukhari. Muridnya yang disukai, Hasyim Asy'ari, membawa tradisi ini ke Indonesia, di mana pesantrennya di Tebu Ireng (Jombang) menjadi terkenal sebagai Pondok Hadis.

Tokoh ketiga adalah Muhammad Hasyim Asy'ari (1287-1366/1870-1947). Beliau adalah tokoh pendiri Nahdhatul Ulama yang mengelola sejumlah besar pesantren. Beliau menulis buku yang berjudul Adab al-Alim wa al-Muta allim fi-ma> Yahtaj Ilay-hi al-Muta allim fi Ahwal Ta'allumihi wa-ma Yatawaqqafu Alay-hi alMu allim fi Maqamat Ta limihi. ${ }^{27}$ Buku ini membahas tentang etika akademis di mana etika menjadi bagian integral dari keseluruhan proses pembelajaran. Karya ini juga semakin mempertegas betapa karya-karya tentang etika akademis muncul di mana saja sebuah sistem pendidikan Islam terbentuk.

Kitab Kuning ini identik dengan pesantren sebagaimana dikemukakan di atas tadi. Saking lengketnya dengan Kitab Kuning, kalangan pesantren mencoba bersikap, memaknai dan menjawab hampir seluruh persoalan yang muncul dan berkembang di masyarakat. Bahkan jika kita tengok halaqah bahsul masail para santri di pesantren, maka seakan-akan seluruh persoalan hidup ini sudah termaktub dan telah dijawab oleh Kitab Kuning. Tak hanya persoalan masa lalu, isu-isu terkini pun pembahasannya sudah ada, atau minimal diasumsikan ada. Sebut saja misalnya, persoalan poligami, dari mulai yang ekstrim pro-poligami dan yang ekstrim kontra-poligami, semua terpapar dalam Kitab Kuning. Pun persoalan formalisasi syariah, perdebatan pornoaksi-pornografi, persoalan sikap terhadap agama lain, dan lain sebagainya juga tersurat dalam Kitab Kuning. Ibarat lautan, semua jenis ikan dapat ditemukan di sana.

Satu hal lagi, terasa ada yang mengganjal kalau berbicara Kitab Kuning kok tidak menyebut Nahdlatul Ulama (NU). Kaitan Kitab Kuning dengan ormas Islam

\footnotetext{
${ }^{26}$ Mawhaba Dhawi '1-Fadl adalah sebuah syarh pada al-Muqaddimat al-Hadramiyyah-nya 'Abdallah Ba-Fadl, dikenal sebagai "Bapadal" di pesantren. Ia dicetak di Mesir, 1315/1897-8, tapi tak ditemukan lagi. Karyanya yang masih ada hanyalah sebuah kitab yang sulit tentang tata bahasa Arab, Minhaj dhawi 'n-Nazar (komentar terhadap Alfiyyah-nya Ibn Malik). 'Abd al-Iabar mencatat 12 karya lain.

${ }^{27}$ Hasan Asari, Menguak Sejarah Mencari 'Ibrah; Risalah Sejarah Sosial-Intelektual Muslim Klasik, (Bandung: Citapustaka Media Perintis, 2006), h. 90.
} 
terbesar di Indonesia ini pun tak terpisahkan. Warga nahdhiyyin menempatkan Kitab Kuning sebagai acuan utama dalam kehidupan sehari-hari. Terutama yang menyangkut masalah hukum ibadah atau ritual, akhlak atau perilaku, dan mu'amalah atau hubungan sosial. ${ }^{28}$ Perilaku warga NU itu tercermin dari cara mereka bersikap. Ketika warga menemui persoalan, rujukannya adalah bertanya ke kiai. Lalu, kiai menjelaskan berdasarkan keterangan dari Kitab Kuning. Mayoritas dalam soal fikih, mereka bermazhab syafi'i, meski Anggaran Dasar NU mengakui keberadaan mazhab fiqh yang empat: Hanafi, Maliki, Syafi`i, Hambali.

Karena itu, Kitab Kuning yang dikaji di pesantren, kebanyakan kitab-kitab karya para ulama Syafi'iyah. Mulai dari kitab fikih tingkat dasar, seperti Safinatun Naja, Taqrib, Kifayatul Akhyar; menengah seperti Fathul Qarib, Fathul Wahhab, Fathul Mu'in, I'anatut Thalibin, Hasyiyah Bajuri, Muhazzab; hingga tingkat tinggi seperti Nihayatul Muhaj, Hasyiyah Qalyubi wa Umairah, Al-Muharrar, Majmu' Syarh Muhazzab. Semuanya merupakan susunan para ulama mazhab Syafi'i. ${ }^{29}$

Jika ditinjau dari jenisnya, Kitab Kuning terdiri dari kitab-kitab nahwu, s\}araf, fiqh, ushul figh, musthalahul hadis, tauhid, tasawuf, tafsir dan kitab-kitab balaghah. Kitab nahwu berisi tentang ilmu-ilmu yang berkaitan dengan seluk beluk kalimat. Kitab sharaf berisikan tentang: ilmu-ilmu yang berkaitan dengan asal-usul kata. Kitab fiqh berisikan tentang: tata cara beribadah, dan bermu'amalah. Kitab ushul fiqh berisi tentang: kaidah-kaidah dan tata cara menetapan suatu hukum syariat. Kitab hadis berisikan tentang: kumpulan hadis-hadis Rasullulah saw., baik yang berkaitan dengan perkataan, perbuatan, maupun hal-hal yang berkaitan dengan perizinannya. Kitab must \}alah\}ul h\}adis| berisikan tentang: ilmu-ilmu untuk mengetahui keotentikan suatu hadis. Kitab tauhid dan kitab tasawuf berisikan tentang: ketuhanan. Kitab tafsir berisikan tentang: penjelasan-penjelasan tentang ayat-ayat suci Alquran. Dan kitab balaghah berisikan tentang: ilmu-ilmu yang berkaitan dengan retorika bahasa arab.

Sedangkan Kitab Kuning dilihat dari penampilan lahiriahnya, memiliki 5 karakter: Pertama: mengulas pembagian suatu yang umum menjadi suatu yang khusus, yang global menjadi terinci dan begitulah seterusnya. Kedua, menyajikan redaksi yang

\footnotetext{
${ }^{28}$ Ini erat kaitannya dengan disiplin ilmu fikih, tentang boleh atau tidaknya melakukan suatu tindakan. Karena itu, meski khazanah Kitab Kuning yang dikembangkan di pesantren begitu luas (seperti fikih, tasawuf, tafsir, hadis, tatabahasa, astronomi, dst.), warga NU kebanyakan menggunakannya dalam konteks pemecahan soal-soal fiqhiyyah untuk suatu kebijakan atau sekedar menjalankan aktifitas ibadah dan muamalah harian.

${ }^{29}$ Azra, Pendidikan Islam, h. 144-145.
} 
teratur dengan menampilkan beberapa pernyataan untuk menuju suatu kesimpulan yang benar-benar dituju. Ketiga, membuat ulasan-ulasan tertentu dalam mengulangi uraian-uraian yang dianggap perlu. Penampilannya tidak semraut dan pola pikirnya dapat dinilai lurus. Keempat, memberikan batasan-batasan yang jelas tentang sebuah definisi. Kelima, menampilkan beberapa alasan terhadap pernyataan yang dianggap perlu. $^{30}$

\section{Penyikapan yang Berkembang Terhadap Kitab Kuning}

Kalau ditelisik, tradisi Kitab Kuning jelas bukan berasal dari Nusantara. Sebagian besar kitab klasik yang dipelajari di Indonesia berbahasa Arab, dan ditulis sebelum Nusantara terislamisasi. Demikian juga banyak syarah bukan berasal dari Indonesia, meskipun jumlah syarah yang ditulis ulama Nusantara makin banyak. Bahkan pergeseran perhatian ulama dalam tradisi itu mengikuti pergeseran serupa di sebagian besar dunia Islam. Sementara sejumlah Kitab Kuning yang ditulis pasca Islamisasi Nusantara, juga sebagian besar tak berasal dari Indonesia, tapi dari Makkah atau Madinah meskipun pengarangnya boleh jadi orang Indonesia. ${ }^{31}$

Memang, sejarah Kitab Kuning merupakan bagian dari sejarah intelektual Islam Indonesia. Meski begitu, genuine Kitab Kuning tidak bisa semata-mata diklaim sebagai tradisi khas Nusantara, sebab Kitab Kuning sendiri sejatinya berakar dari khazanah intelektual di Timur Tengah, khususnya di Mekkah. Maka tak heran jika Martin van Bruinessen mempertanyakan asal-usul tradisi intelektual Kitab Kuning di Nusantara. "Benar-benar tradisi Indonesia atau asing?"32 pertanyaan itulah yang mengemuka.

Untuk melihat posisi dan sejauhmana makna penting Kitab Kuning ini, setidaknya ada beberapa abstraksi yang perlu dicermati. Pertama, cara pandang masyarakat terhadap pesantren sebagai lembaga yang identik dengan Kitab Kuning. Pesantren jamaknya dipandang sebagai sebuah 'subkultur' yang mengembangkan pola kehidupan yang tidak seperti biasa atau katakanlah unik. Di samping faktor kepemimpinan kiai-ulama, Kitab Kuning adalah faktor penting yang menjadi karakteristik subkultur itu. Kitab Kuning seakan menjadi kitab pusaka yang

\footnotetext{
${ }^{30}$ A. Chozin Nasuha, Epistemologi Kitab Kuning dalam Pesantren”. (Jakarta: t.p., 1989), h. 28.

${ }^{31}$ Martin van Bruinessen, Pesantren dan Kitab Kuning; Pemeliharaan dan Kesinambungan Tradisi Pesantren, Ulumul Quran III (4), 1992, h. 75.

${ }^{32}$ Ibid.
} 
mandraguna. Kitab yang terus 'diwariskan' turun temurun dari generasi ke generasi, sebagai sumber bacaan utama bagi masyarakat pesantren yang cukup luas. Dengan begitu, ini merupakan bagian dari sebuah proses berlangsungnya pembentukan dan pemeliharaan subkultur yang unik tersebut.

Kedua, Kitab Kuning juga difungsikan oleh kalangan pesantren sebagai 'referensi' nilai universal dalam menyikapi segala tantangan kehidupan. Karena itu, bagaimanapun perubahan dalam tata kehidupan, Kitab Kuning harus tetap terjaga. Kitab Kuning dipahami sebagai mata rantai keilmuan Islam yang dapat bersambung hingga pemahaman keilmuan Islam masa tabiin dan sahabat. Makanya, memutuskan mata rantai Kitab Kuning, sama artinya membuang sebagian sejarah intelektual umat. Kita mungkin sering mendengar sebuah hadis yang disabdakan oleh Rasulullah saw. "Al- 'Ulama Warosatul Anbiya", ulama adalah pewaris para Nabi.

“Apapun masalahnya, jawabnya adalah Kitab Kuning.” Itulah ungkapan mudah untuk menggambarkan betapa luasnya khazanah dalam Kitab Kuning seperti dipahami kalangan pesantren, sehingga semua masalah dapat terselesaikan olehnya. Ini dimantapkan dengan beberapa cerita tentang keampuhan Kitab Kuning dalam menyelesaikan personalan kebangsaan. Misalnya, cerita peran Kitab Kuning di zaman trikora, tahun 1961. ${ }^{33}$ Alkisah, Kiai Wahab Hasbullah pernah melakukan kontekstualisasi Kitab Kuning yang berjudul Fathul Qarib yang kemudian oleh Bung Karno dijadikan sebagai dasar penyelesaian konflik Irian Barat antara Indonesia dan Belanda. Pemerintah kerajaan Belanda secara resmi pernah berjanji kepada pemerintahan RI, bahwa Irian Barat akan diserahkan kepada Indonesia pada tahun 1948. ternyata sampai tahun 1951 Belanda masih belum menyerahkan kedaulatan atas Irian Barat.

Setelah beberapa kali diadakan perundingan untuk menyelesaikan Irian Barat dan selalu gagal. Bung Karno kemudian menghubungi Kiai Wahab Hasbullah di Jombang. Bung Karno menanyakan bagaimana hukumnya orang-orang Belanda yang masih bercokol di Irian Barat?

$\begin{array}{ccccccc}\text { "Hukumnya } & \text { sama dengan orang yang ghosob," kata Kiai Wahab. } \\ \text { "Apa artinya ghosob itu pak kiai?" tanya Bung Karno. }\end{array}$

${ }^{33}$ Cerita ini dirilis di situs Keluarga Muslim Delft Netherland, www.muslimdelft.nl, berdasarkan cerita dari KH. Dimyati, Kendal, yang disampaikan kepada Ustadz Khariri Makmun saat ia mengunjungi Kyai Dimyati. Khariri Makmun adalah Rois Syuriah Komunitas Muda Nahdatul Ulama Jepang (KMNU-Nihon) periode 2004-2005. 
"Ghosob itu istihqoqu malil ghoir bighoiri iznihi, menguasai hak milik orang lain tanpa izin," jawab Kiai Wahab. "Lalu bagaimana solusinya untuk menghadapi orang yang ghosob?" “Adakan perdamaian," jawab Kiai Wahab. Lalu Bung Karno bertanya lagi, "Menurut insting pak Kiai apakah jika diadakan perundingan damai akan berhasil?" “Tidak," jawab Kiai Wahab. "Lalu kenapa kita tidak potong kompas aja pak Kiai?" Kata Bung Karno. “Tidak boleh potong kompas menurut syari'ah,” jawab kiai Wahab.

Selanjutnya, sesuai anjuran Kiai Wahab untuk berunding dengan Belanda, Bung Karno mengutus Subandrio untuk mengadakan perundingan konflik Irian Barat dengan Belanda. Perundingan inipun akhirnya gagal. Kegagalan inipun disampaikan oleh Bung Karno kepada Kiai Wahab. Lalu Bung Karno bertanya lagi, pak Kiai apa solusi selanjutnya untuk menyelesaikan konflik Irian Barat. Kiai Wahab menjawab, "akhazahu qahrun", ambil atau kuasai dengan paksa. Bung Karno bertanya lagi, “Apa rujukan pak Kiai dalam memutuskan masalah ini?" "Saya mengambil literatur kitab Fathul Qarib dan syarahnya, al-Baijuri," tegas kiai Wahab. Setelah Bung Karno mantap dengan pendapat Kiai Wahab yang mengkontekstualisasi literatur kitab Fathul Qarib agar Irian Barat dikuasai atau direbut dengan paksa, kemudian Bung Karno membentuk Trikora (tiga komando rakyat).

Ketiga, segi dinamis yang diperlihatkan Kitab Kuning. Kalau ditelisik, ternyata segi dinamisnya adalah transfer pembentukan tradisi keilmuan fikih-sufistik yang didukung penguasaan ilmu-ilmu instrumental, termasuk ilmu-ilmu humanistik (adab). Tanpa Kitab Kuning, dalam pengertian yang lebih kompleks, tradisi intelektual di Indonesia agaknya tidak akan bisa keluar dari kemelut sufi-ektrem dan fikih-ekstrem. Pesantren yang akrab dengan khazanah klasik Kitab Kuning inilah yang membedakan dengan pesantren-pesantren lain yang lebih cenderung pada adopsi terhadap keilmuan Barat. Melalui ini pula, pesantren melahirkan sikap-sikap yang tasamuh (lapang dada), tawazun (seimbang), dan i'tidal (adil). Dengan begitu, sulit diramalkan akan terjadinya sikap ekstrem atau radikal yang saat ini tengah menjadi hantu menakutkan bagi dunia.

Keempat, pemilihan Kitab Kuning sebagai referensi utama di pesantren, tentu terkait dengan perkembangan tradisi intelektual Islam Nusantara. Sejak periode paling dini, bersamaan dengan proses internasionalisasi, yang berarti Arabisasi, dokumentasi tentang ajaran-ajaran Islam selalu ditulis dalam bahasa Arab, sekurang-kurangnya dengan menggunakan huruf Arab. Arabisasi seperti ini tidak lain menempatkan 
keislaman di Indonesia selalu dalam konteks universal. Proses seperti ini terus berlanjut sejalan dengan semakin kuatnya intervensi bahasa Arab ke dalam bahasabahasa di Nusantara, dan pesantren tampaknya hanya melanjutkan proses ini saja. Hal ini mencapai momentumnya ketika pesantren berada dalam tekanan kekualan asing, dan ia melakukan gerakan defensif non kooperatif. Pemasok utama nilai dan pengetahuan yang dapat dipercaya dalam situasi seperti itu adalah Kitab Kuning yang sudah beredar sangat luas di lingkungan mereka.

Terkait dengan hal ini, Abdurrahman Wahid justru menyoroti segi dinamis dari perkembangannya di pesantren. Menurutnya, Kitab Kuning merupakan faktor penting dalam pembentukan tradisi keilmuan yang fiqih-sufistik, yang didukung penguasaan ilmu-ilmu instrumental, termasuk ilmu-ilmu humanistik (adab)-nya. Tanpa Kitab Kuning dalam pengertian yang lebih kompleks, tradisi intelektual di Indonesia agaknya tidak akan bisa keluar dari kemelut sufi-ekstrem dan fiqih-ekstrem. Apa yang dicapai oleh Kiai Ihsan Jampes melalui karya-karyanya, Siraj al-Thalibin dan Manahij alImdad, yang masing-masing merupakan komentar atas Minhaj al- 'Abidin dan Irsyad $a l$-'Ibad, merupakan contoh prestasi intelektual yang mengandalkan Kitab Kuning. Dalam Manahij al-Imdad ini, sekali lagi, telah membuktikan kepiawaian ulama pesantren dalam mengkombinasikan kemampuan mendalami ilmu-ilmu agama secara tuntas dan mengamalkan tasawuf secara tuntas pula. ${ }^{34}$

Keempat abstraksi di atas paling tidak memberikan gambaran luas bagaimana sesungguhnya pergumulan Kitab Kuning sebagai sebuah khazanah di kalangan pesantren. Dengan begitu, usai mencermati beberapa gambaran di atas, jika disederhanakan, setidaknya ada dua poin penting yang dapat menjelaskan posisi dan signifikansi Kitab Kuning di pesantren.

Poin pertama, otentisitas Kitab Kuning bagi kalangan pesantren adalah referensi yang kandungannya sudah tidak perlu dipertanyakan lagi. Kenyataan bahwa Kitab Kuning yang ditulis sejak lama dan terus dipakai dari masa ke masa menunjukkan bahwa kitab tersebut sudah teruji kebenarannya dalam sejarah. Kitab Kuning dipandang sebagai pemasok teori dan ajaran yang sudah sedemikian rupa dirumuskan oleh para ulama dengan bersandar pada Alquran dan Hadis Nabi. Menjadikan Kitab Kuning sebagai referensi tidak berarti mengabaikan Alquran-Hadis, melainkan justru pada hakikatnya mengamalkan ajaran keduanya. Kepercayaan bahwa

\footnotetext{
${ }^{34}$ Abdurrahman Wahid, Asal-usul, h. 11.
} 
kedua kitab itu merupakan wahyu Allah menimbulkan pengertian bahwa Alquran dan Hadis Nabi tidak boleh diperlakukan dan dipahami sembarangan. Cara paling aman untuk memahami kedua sumber utama itu agar tidak terjerumus dalam kesalahan dan kekeliruan yang dibuatnya sendiri adalah mempelajari dan mengembangkan khazanah Kitab Kuning. Sebab, kandungan Kitab Kuning merupakan penjelasan dan pengejawantahan yang siap pakai dan rumusan ketentuan hukum yang bersumber dari Alquran dan Hadis Nabi yang dipersiapkan oleh para mujtahid di segala bidang.

Poin kedua, Kitab Kuning sangatlah penting bagi pesantren untuk memfasilitasi proses pemahaman keagamaan yang mendalam sehingga mampu merumuskan penjelasan yang segar tetapi tidak ahistoris mengenai ajaran Islam, Alquran, dan Hadis Nabi. Kitab Kuning mencerminkan pemikiran keagamaan yang lahir dan berkembang sepanjang sejarah peradaban Islam. Untuk menjadikan pesantren tetap sebagai pusat kajian keislaman, pemeliharaan dan bahkan pengayaan Kitab Kuning harus tetap menjadi ciri utamanya. Termasuk dalam proses pengayaan ini adalah penanganan kitab kuning dalam bidang dan masa luas, termasuk yang lahir belakangan, yakni al-kutub al-ashriyyah. Hanya dengan penguasaan Kitab Kuning seperti inilah kreasi dan dinamika pemikiran Islam yang serius di Indonesia tidak akan berhenti.

\section{Apresiasi Kritis Terhadap Kitab Kuning}

Gambaran singkat tentang tradisi Kitab Kuning di atas menunjukkan betapa pesantren sebagai sebuah institusi perlu berupaya keras untuk mempertahankan jatidirinya sambil terus mengadakan pengembangan tradisi dan orientasinya. Salah satu hal yang mungkin sangat penting dipikirkan pesantren adalah menyangkut pola pemikiran Kitab Kuning yang selama ini dianut. Tanpa harus mengabaikan Kitab Kuning yang sarat dengan warna Ahl al-Hadis dan sufismenya, Kitab Kuning dengan pola Ahl ar-Ra'yu barangkali sudah saatnya menjadi pilihan mendesak. Ini berarti bahwa pemikiran tentang ide dasar dan kausa (illah) dari sebuah teks menjadi perhatian yang lain. Sebab, cara seperti ini akan memungkinkan seseorang melakukan pengembangan-pengembangan atasnya. Ide dasar suatu teks sudah tentu tidak dapat dilepaskan dari kepentingan-kepentingan yang menyertainya. Ia dapat berupa maksudmaksud (maqashid) atau hikmah-hikmah (al-hikam). Atas dasar inilah seluruh bangunan keagamaan dihadirkan. Sementara itu, kausa (illah) akan menjadi dasar untuk menjustifikasi persoalan-persoalan sejenis atau mirip. Ia juga dijadikan dasar 
untuk perubahan-perubahan pemahaman bila ternyata dalam konteks tertentu kausa itu telah berubah. Pola pemikiran seperti ini akan sangat strategis bagi sebuah kehidupan yang senantiasa berubah dan berkembang dewasa ini.

Pilihan untuk melakukan pengembangan pola Kitab Kuning memerlukan pula perluasan literatur yang digunakan. Ini berarti Kitab Kuning bercorak ahl al-ra'y akan menjadi kebutuhan dan sudah waktunya diterima dengan apresiasi yang tinggi oleh masyarakat pesantren. Keterbukaan untuk menerima kitab-kitab kontemporer barangkali tidak ada salahnya. Misalnya karya-karya fuqaha al-'Ashr al-Hadits, antara lain: Shah Wali Allah al Dihlawi, Muhib Allah al-Bahari, al-Nablusi, al-Syaukani, Muhammad Khidr Husain, dan lain-lain, atau yang lebih belakangan seperti Sa'id Ramdhan al-Buthi, Dr. Wahbah al-Zuhaili, Syeikh Abu Zahrah, untuk menyebut beberapa saja yang relatif cukup popular. Saya kira dalam beberapa kali muktamar NU, beberapa kitab ini sudah disebut-sebut dan dijadikan rujukan dalam menjawab isu-isu kontemporer. Di luar itu masih sangat banyak kitab-kitab kontemporer yang bisa kita cari perpustakaan-perpustakaan dan toko-toko buku di dunia Arab.

Selain memahami pikiran-pikiran berikut argumen yang melandasinya, perluasan Kitab Kuning juga diperlukan agar dapat dijadikan sebagai bahan komparasi dalam memberikan jawaban atas persoalan-persoalan kontemporer yang mungkin tidak dijumpai secara tekstual dalam Kitab Kuning konvensional. Kenyataan yang berkembang selama ini menunjukkan bahwa terdapat sejumlah kasus yang justru mendapat jawaban dari Kitab Kuning alternatif itu. Dalam masalah asuransi, misalnya, referensi yang diajukan ternyata ditemukan dalam karya Ibn Abidin al-Hanafi.

Perluasan literatur Kitab Kuning juga dapat mengambil bentuk kajian yang bersifat wawasan dalam mengantarkan materi Kitab Kuning itu sendiri. Istilah populer literatur ini adalah Madkhal (pengantar), termasuk tarîkh at-Tasyri' dalam bidang fiqh. Terus terang, Kitab Kuning madkhal selama ini tidak banyak diajarkan di pesantren. Ia masih dipandang sebagai kitab obrolan dan tidak praktis (kondo). Padahal, melalui literatur ini, akan di temukan suatu kerangka dasar dari kebangunan keilmuan yang dikaji. Dalam beberapa dekade terakhir, kitab-kitab yang menjelaskan tentang sejarah perkembangan hukum Islam sangatlah banyak. Dari pembacaan atasnya, kita mengenal fase-fase zaman munculnya para mujtahid besar, masa keemasan fiqh Islam, zaman kemunduran dan kejumudannya. Dan kita tentu dapat mempelajari mengapa hal itu semua ada. 


\section{PENUTUP}

Berdasarkan catatan sejarah, pesantren sebagai sebuah lembaga pendidikan Islam sejak era awal telah menggunakan Kitab Kuning, di sebagian tempat disebut pula sebagai kitab klasik untuk menyebut jenis kitab yang sama dan disebut juga kitab turas. Kitab-kitab tersebut umumnya tidak diberi harakat/syakal, sehingga tidak jarang disebut juga sebagai "kitab gundul". Disebut Kitab Kuning karena pada umumnya kitab-kitab tersebut dicetak di atas kertas berwarna kuning.

Kitab Kuning merupakan kitab-kitab keagamaan berbahasa Arab, Melayu, Jawa atau bahasa-bahasa lokal lain di Indonesia dengan menggunakan aksara Arab, yang selain ditulis oleh ulama Timur Tengah, juga ditulis oleh ulama Indonesia sendiri. Pengertian ini merupakan perluasan dari terminologi Kitab Kuning yang selama ini, yaitu kitab-kitab keagamaan berbahasa Arab, menggunakan Kitab Kuning relevan dengan kehidupan sekarang.

Di daerah asalnya, diseputar Timur Tengah, Kitab Kuning ini disebut al-kutub al-qadimah, sebagai sandingan dari al-kutub al-ashriyah, al-kutub al-qadimah yang beredar di kalangan pesantren di Indonesia terbatas jenisnya. Yang sangat dikenal ialah kitab-kitab fiqih, tasawuf, tafsir, hadis, tauhid dan tarikh, yang semuanya termasuk kelompok-kelompok syariah, yang banyak dikenal ialah kitab-kitab nahwu dan sharaf, yang mutlak diperlukan sebagai ilmu bantu.

Kitab-Kitab Kuning kebanyakan muncul pada masa sesudah kitab al-Umm Imam al-Syafi'i dan kitab al-Muwaththa' Imam Malik, berasal dari kalangan mujtahid mazhab ataupun mujtahid muntasib yang ditulis pada abad ke 10 sampai 15 M., tapi bukan berarti bahwa sesudah masa itu tidak ada kitab yang dihasilkan seperti tampak pada karya-karya belakangan seperti karangan Syekh Nawawi al-Bantani al-Jawi pada Abad ke-19.

Sedangkan kitab-kitab yang dikarang pada abad ke-20-an seringkali disebut sebagai kitab muta'akhirah (belakangan). Tentang kitab-kitab belakangan ini tidak dapat dikategorikan sebagai Kitab Kuning ataupun kitab klasik walau juga ada yang menyebutnya sebagai Kitab Kuning tapi bukan klasik. Bagi penulis sendiri lebih menyetujui untuk menyebut kitab yang dikarang pada abad ke-20 sebagai kitab muta'akhirah.

Sependek penelusuran yang saya lakukan, paling tidak ada tiga tokoh penulis pada abad ke-20 yang menulis Kitab Kuning. Pertama, yaitu Ahmad Khatib (w. 1915) 
Minangkabau -bapak reformis Islam Indonesia- yang juga adalah murid dari Syekh Nawawi al-Bantani (w. 1896). Kedua, Kyai Mahfuz Termas (w. 1919-20), Dia menyelesaikan pendidikannya di bawah bimbingan guru-guru Arab terbesar di Masjid al-Haram dan juga menjadi ahli qiraat al-Qur'an (dia menulis banyak kitab tentang itu). Karyanya yang paling besar adalah empat jilid kitab fiqh, yang merupakan komentar (hasyiyah) terhadap kitab yang banyak dipakai di Indonesia, dan dia tampaknya telah menjadi ulama Indonesia pertama yang mengajar kitab Hadis Shahih Bukhari. Ketiga adalah Muhammad Hasyim Asy ári (1287-1366/1870-1947). Beliau adalah tokoh pendiri Nahdhatul Ulama yang mengelola sejumlah besar pesantren. Beliau menulis buku yang berjudul Adab al-Alim wa al-Muta allim fi-ma Yahtaj Ilayhi al-Muta allim fi Ahwal Ta'allumihi wa-ma Yatawaqqafu Alay-hi al-Mu'allim fi Maqamat Ta limihi. Buku ini membahas tentang etika akademis di mana etika menjadi bagian integral dari keseluruhan proses pembelajaran. Karya ini juga semakin mempertegas betapa karya-karya tentang etika akademis muncul di mana saja sebuah sistem pendidikan Islam terbentuk.

Ada dua poin penting yang dapat menjelaskan posisi dan signifikansi Kitab Kuning di pesantren. Poin pertama, otentisitas Kitab Kuning bagi kalangan pesantren adalah referensi yang kandungannya sudah tidak perlu dipertanyakan lagi. Kenyataan bahwa Kitab Kuning yang ditulis sejak lama dan terus dipakai dari masa ke masa menunjukkan bahwa kitab tersebut sudah teruji kebenarannya dalam sejarah. Kitab Kuning dipandang sebagai pemasok teori dan ajaran yang sudah sedemikian rupa dirumuskan oleh para ulama dengan bersandar pada Alquran dan Hadis Nabi. Poin kedua, Kitab Kuning sangatlah penting bagi pesantren untuk memfasilitasi proses pemahaman keagamaan yang mendalam sehingga mampu merumuskan penjelasan yang segar tetapi tidak ahistoris mengenai ajaran Islam, Alquran, dan Hadis Nabi.

Gambaran singkat tentang tradisi Kitab Kuning di atas menunjukkan betapa pesantren sebagai sebuah institusi perlu berupaya keras untuk mempertahankan jatidirinya sambil terus mengadakan pengembangan tradisi dan orientasinya. Salah satu hal yang mungkin sangat penting dipikirkan pesantren adalah menyangkut pola pemikiran Kitab Kuning yang selama ini dianut. Tanpa harus mengabaikan Kitab Kuning yang sarat dengan warna Ahl al-Hadis dan sufismenya, Kitab Kuning dengan pola Ahl ar-Ra'yu barangkali sudah saatnya menjadi pilihan mendesak. Selain memahami pikiran-pikiran berikut argumen yang melandasinya, perluasan Kitab 
Kuning juga diperlukan agar dapat dijadikan sebagai bahan komparasi dalam memberikan jawaban atas persoalan-persoalan kontemporer yang mungkin tidak dijumpai secara tekstual dalam Kitab Kuning konvensional.

\section{DAFTAR PUSTAKA}

Abdullah, Taufik, Pemikiran Islam di Nusantara dalam Perspektif Sejarah: Sebuah Sketsa, (Prisma, cet. III, 1991).

Asari, Hasan, Menguak Sejarah Mencari Ibrah; Risalah Sejarah Sosial-Intelektual Muslim Klasik, (Bandung: Citapustaka Media Perintis, 2006).

Azra, Azyumardi, Pendidikan Islam: Tradisi dan Modernisasi di Tengah Tantangan Milenium III, (Jakarta: Kencana Prenada Media, cet. 1, 2012). , Pemikiran Sosio-Politik Islam dalam Kitab Melayu/Jawa Klasik, makalah pada Simposium Nasional I Kitab Kuning dan Lektur Islam, Bogor: ICMI, 1994.

Departemen Agama, Dirjen Kelembagaan Agama Islam, Pondok Pesantren dan Madrasah Diniyah, (Jakarta: Depag, 2003).

Haedari, H.M. Amin, et.al., Masa Depan Pesantren, Dalam Tantangan Modernitas dan Tantangan Kmpleksitas Global, (Jakarta: IRD Press, 2005).

Mahfud, Sahal, Nuansa Fiqih Sosial, (Yogyakarta: LkiS,1994).

Mochtar, Afandi, Kitab Kuning dan Tradisi Akademik Pesantren, (Bekasi: Pustaka Isfahan, 2008).

Nasuha, A. Chozin, Epistemologi Kitab Kuning dalam Pesantren”. (Jakarta: t.p., 1989).

Van Bruinessen, Martin, Kitab Kuning, Pesantren dan Tarekat, (Bandung: Mizan, Cet.III, 1999).

, Pesantren and Kitab Kuning: Maintenance and Continuation of A Tradition of Religious Learning, (Bandung: Mizan, 1992).

, Pesantren dan Kitab Kuning; Pemeliharaan dan Kesinambungan Tradisi Pesantren, Ulumul Quran III (4), 1992.

Wahid, Abdurrahman, Asal-Usul Tradisi Keilmuan di Pesantren, Jurnal Pesantren, No Perdana (1984).

, Pesantren Masa Depan Wacana Pemberdayaan dan Transformasi Pesantren, (Bandung: Pustaka Hidayah, 1999).

Yafie, Ali, Menggagas Fiqih Sosial dari Soal Lingkungan Hidup, Asuransi Hingga Ukhuwah, (Bandung: Mizan, 1994). 